IZA DP No. 5191

Wage Subsidies, Work Incentives, and the Reform of the Austrian Welfare System

Viktor Steiner

Florian Wakolbinger

September 2010 


\title{
Wage Subsidies, Work Incentives, and the Reform of the Austrian Welfare System
}

\author{
Viktor Steiner \\ Free University Berlin, \\ DIW Berlin and IZA \\ Florian Wakolbinger \\ GAW Innsbruck \\ and University of Linz
}

\section{Discussion Paper No. 5191 \\ September 2010}

\author{
IZA \\ P.O. Box 7240 \\ 53072 Bonn \\ Germany \\ Phone: +49-228-3894-0 \\ Fax: +49-228-3894-180 \\ E-mail: iza@iza.org
}

\begin{abstract}
Any opinions expressed here are those of the author(s) and not those of IZA. Research published in this series may include views on policy, but the institute itself takes no institutional policy positions.

The Institute for the Study of Labor (IZA) in Bonn is a local and virtual international research center and a place of communication between science, politics and business. IZA is an independent nonprofit organization supported by Deutsche Post Foundation. The center is associated with the University of Bonn and offers a stimulating research environment through its international network, workshops and conferences, data service, project support, research visits and doctoral program. IZA engages in (i) original and internationally competitive research in all fields of labor economics, (ii) development of policy concepts, and (iii) dissemination of research results and concepts to the interested public.
\end{abstract}

IZA Discussion Papers often represent preliminary work and are circulated to encourage discussion. Citation of such a paper should account for its provisional character. A revised version may be available directly from the author. 


\section{ABSTRACT \\ Wage Subsidies, Work Incentives, and the Reform of the Austrian Welfare System ${ }^{*}$}

We analyze the labor supply and income effects of a needs-based minimum benefit system ("Bedarfsorientierte Mindestsicherung") to be introduced in Austria by the end of this/beginning of next year. The aim of this reform is to reduce poverty as well as increasing employment rates of recipients of social assistance. On the basis of a behavioral microsimulation model we show that this new system will slightly increase incomes for the poorest households and slightly reduce labor supply due to the generous allowances for marginal employment under the current and the planned regulations of unemployment assistance. As an alternative, we analyze a reform proposal which reduces financial incentives for marginal employment not covered by social security, and rewards working longer hours by a wage subsidy. Although this alternative reform would yield modest positive labor supply effects, a relatively large number of households would suffer income losses.

JEL Classification: $\quad H 31,138, \mathrm{~J} 22$

Keywords: $\quad$ work incentives, labor supply, social safety system, microsimulation

Corresponding author:

Viktor Steiner

DIW Berlin

Mohrenstraße 58

10117 Berlin

Germany

E-mail: vsteiner@diw.de

\footnotetext{
* We thank participants at the 2010 meeting of the Austrian Economic Association (NOEG) in Vienna, the 2010 meeting of the Public Economics group of the Association of German-Speaking Economist (Verein fuer Socialpolitik) in Budapest, and of a research seminar at the Vienna University of Economics for helpful suggestions on a previous version of this paper. Financial support by the German Science Foundation (DFG) under the project "Work Incentives, Earnings-Related Subsidies, and Emplomyent in Low-Wage Labor Markets - Empirical Analysis and Policy Simulations for Germany" (Ste 681/5-3) is gratefully acknowledged.
} 


\section{Introduction}

Unemployment rates in Austria are traditionally lower than in most other OECD countries (see, e.g. OECD, 2010, for the latest rates), although unemployment of lowqualified Austrians has recently been strongly increasing. For example, the rate among men having completed only compulsory education increased from $7.2 \%$ in autumn 2008 to $12.5 \%$ a year later. For low-qualified women, the rate increased from $8.6 \%$ to $10.4 \%$ in the same period (Statistik Austria, 2009).

Thus, designing policy measures capable of reducing unemployment among lowqualified persons and improving incentives to take up low-wage jobs is a primary issue on the social policy agenda in Austria as well as its fellow OECD countries. In the US and the UK, for example, wage subsidies like the "earned income tax credit" (EITC) or "family credits" have been in place for many years (see, e.g., Meyer and Holtz-Eakin, 2002; Blundell, 2006) and have in the recent past provoked interest of policy advisors also in Germany and Austria (Steiner, 2006). In Germany, several proposals aimed at improving the opportunities to earn money with low wage jobs have recently been brought up. Some of these proposals feature wage-subsidies for recipients of means-tested unemployment assistance who take up jobs with a few hours of work, but also cutbacks of transfers for the unemployed rejecting job offers (see, e.g. Sinn et al, 2006, Steiner, 2004), which probably is why politicians have been reluctant to support them. Other recent proposals favor wage-subsidies to employees earning low hourly wages in jobs covered by the social security system and the abolishment of the implicit subsidy of so called "mini-jobs” which are exempt from social security contribution (see Haan and Steiner, 2007 for an evaluation of alternative recent reform proposals).

In Austria, the system of social assistance, which is organized by the federal states and features different rules in each of the nine states, will be replaced by a comprehensive system called needs-based minimum benefit” (“Bedarfsorientierte Mindestsicherung” BMS) by the end of this/beginning of next year. While within the existing system of social assistance in Austria, transfer applicants have to turn to the local municipalities, receivers of BMS are to be supervised by the unemployment agency (“Arbeitsmarktservice”). The primary aims of the new system are combating poverty, harmonizing the different existing regulations and preventing non-take up. However, the new system is also intended to work as a stepping stone enabling the unemployed to move into regular full-time employment in due course.

In this study we show that the introduction of the proposed BMS will hardly improve financial incentives to take up or increase employment. In fact, our simulation results show even a small overall decline in labor market participation and total working hours. We, there- 
fore, also evaluate an alternative reform proposal which combines the same standard rates as the BMS proposal and somewhat more generous financial incentives to take up regular employment including (partial) refunds of the social security contributions as well transfer cutbacks for people who are reluctant to take up a job. Our simulation results show that, although this reform alternative would yield modest positive labor supply effects, a relatively large number of households would suffer income losses. This illustrates, the budgetary constraints, the limitations of increasing financial work incentives in welfare states with a relatively high level of means-tested out-of-work benefits, of which Austria is a prime example.

The paper is structured as follows. Section 2 introduces the prevailing system of unemployment benefits and social assistance, the BMS as well as the alternative reform proposal analyzed here. Section 3 describes our simulation approach. Simulation results showing the effects of the BMS and the alternative reform proposal on household budget constraints, labor supply, household incomes and fiscal costs are reported and discussed in Section 4, and Section 5 concludes.

\section{The prevailing and planned social welfare systems, and an alternative reform proposal}

\subsection{The prevailing welfare system}

Currently, the Austrian system of social safety features, next to quite generous and universal allowances for childcare and children, two types of unemployment insurance payments and a means-tested social assistance system. If a person becomes unemployed, she will receive the "unemployment benefit” (“Arbeitslosengeld”, UB) for the first 20 weeks ${ }^{1}$ of unemployment. The amount of this transfer is $55 \%$ of the previous net income and paid as a daily benefit. In 2010 the maximum monthly UB amount is 55 percent of the upper social security threshold of $€ 4110$. Since the UB is considered to be based on the insurance principle (AMS, 2009), it is not means tested.

Thereafter there is "unemployment assistance” ("Notstandshilfe”, UA) until unemployment ends. It is slightly smaller (92\%) than the UB and means tested. However, there are generous allowances for income of spouses, and income of other household members does not count at all. The maximum amount is $€ 901$ and $€ 772.4$ per month, depending on how long

\footnotetext{
${ }^{1}$ If the employee has been employed for at least 156 weeks during the last 5 years, the UB is paid for 30 weeks. If the employee is older than 40 and has been employed for at least 312 weeks during the last 10 years, the duration is 40 weeks, and for employees older than 50 who have been employed for 468 weeks during the last 15 years, the duration is 52 weeks.
} 
the UB has been received prior to receiving UA. Both payments require showing efforts in finding a job as well as being able to take up a new job. Both the UB and UA include a small family supplement of $€ 29.7$ per month and dependent child (AMS, 2009).

Also, for recipients of both UB and UA there is an allowance on earnings of up to $€ 366.33$ (paid 14 times a year ${ }^{2}$ ), while there is no such allowance for recipients of social assistance. For earnings exceeding this amount, the benefit-withdrawal rate of UB and UA is 100 percent. As Figure 1 shows, this implies that the monthly net income of a single person receiving an hourly wage at the $25^{\text {th }}$ percentile of the wage distribution and working 30 hours a week is the same as receiving UA and when working only 9 hours.

Figure 1: Budget constraints for a single person without children and eligible to unemployment assistance

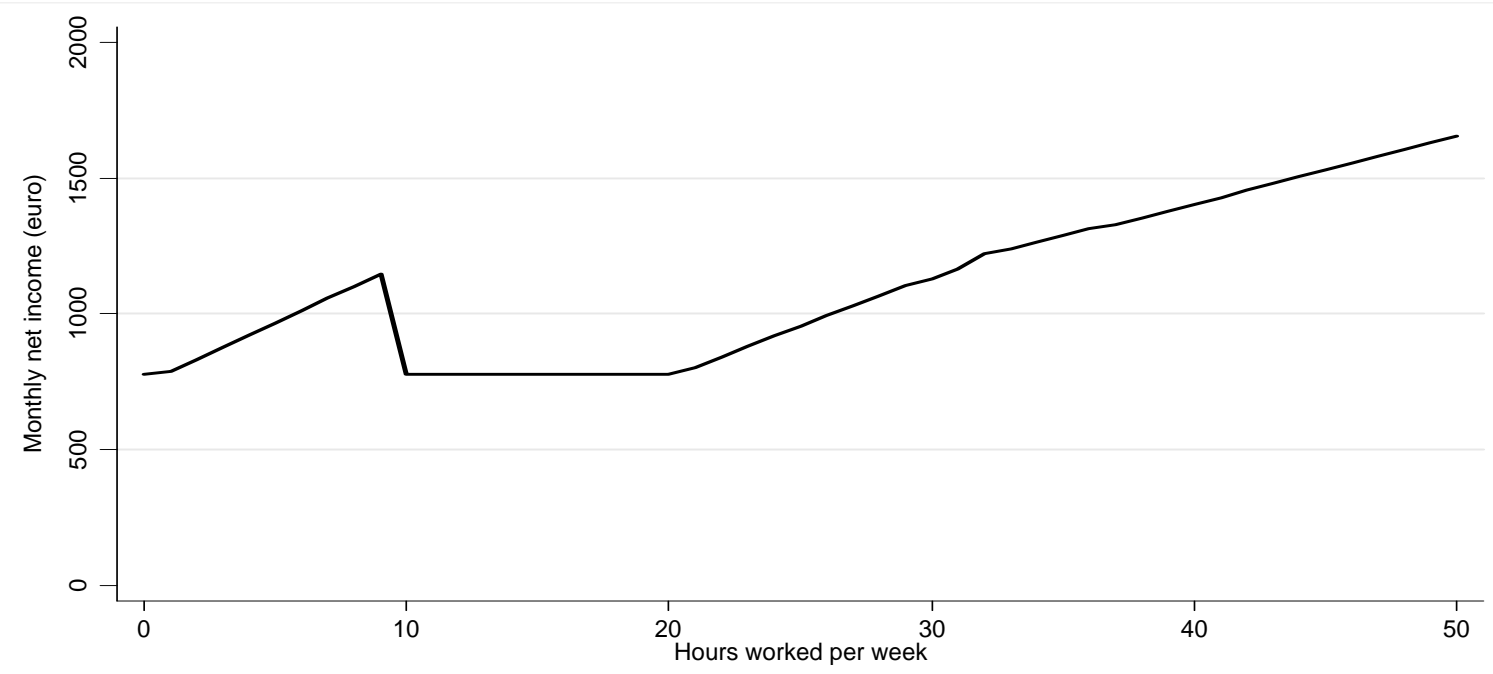

Source: ATTM

Note: We assume an hourly wage of $€ 10.7$, which is the $25^{\text {th }}$ percentile of the observed hourly wages (both genders), and that this person has been employed for 40 hours per week prior to unemployment (which determines the amount of the unemployment assistance payments.

Figure 1 also shows that the third pillar of the Austrian social safety system, social assistance ("Sozialhilfe", SA), applies and supplements household income in case it is lower than some pre-specified standard rate. In the case shown in the graph, the standard rate ${ }^{3}$ is as high as the income of a person receiving the $25^{\text {th }}$ percentile of the hourly wage distribution and working 20 hours per week.

\footnotetext{
${ }^{2}$ Typically, in Austria wages are paid 14 times a year (12 monthly payments plus a holiday and a Christmas allowance, each accounting for one regular monthly wage payment).

${ }^{3}$ Since the standard rates differ across the nine federal states, we show the standard rate for Vienna in this and all the following graphs.
} 
Since single-parents are often not able to take up a job due to child care responsibilities and the limited availability of subsidized child care facilities, and are therefore not eligible to UB or UA, this group represents a large share of all persons receiving SA. Moreover, selfemployed persons with no income and no entitlement to unemployment insurance payments are also entitled to SA. Finally, since there is no lower limit for UB and UA, social assistance might be paid to supplement UB or UA payments, if these are lower than the standard rates for SA.

The amount of social assistance is determined by the difference between a respective standard rate and actual household income, including all sources of income plus transfer income plus realizable ("exploitable”) assets. ${ }^{45}$. Standard rates for SA are intended to cover the typical cost of living at the bottom of the distribution of household incomes. All federal states provide additional payments for renting, and some states also irregular payments, including the coverage of the costs for heating in winter or for clothing. Recipients of SA are also entitled to free medical treatment by use of a special health insurance certificate ("Sozialhilfekrankenschein”).

Typically, the standard rates of SA are paid 14 times a year, which results in quite generous benefits. Table 1 shows the monthly benefits in the existing social safety system as well as in the planned system ("Bedarfsorientierte Mindestsicherung") and the alternative reform proposal described below. We have taken into consideration that the existing system typically features 14 payments a year and have thus adjusted the values such that they represent monthly payments made 12 times a year.

As shown by Table 1, the payments vary considerably across the federal states, and some payments are fairly generous. The drawback of this generosity is that the SA payments introduce an "implicit” minimum wage (Sinn et al., 2006, Müller and Steiner, 2010) since people are likely to be unwilling to take up a job yielding less than the SA payment. Note however, that prior to receiving SA payments, all financial as well as other assets will have to be exploited $^{6}$ such that many people are reluctant to take the benefit instead of a job. If the federal state has no maximum payment for renting, the rates shown in Table 1 include the median of renting costs observed in our data.

\footnotetext{
${ }^{4}$ These are monetary assets as well as property not used for own residence. There are, however, restrictions in some federal states. In Carinthia, for example, monetary assets up to $€$ 7,590 do not reduce the amount of social assistance.

${ }^{5}$ The nationwide family allowances are not included in the income subtracted from the standard rates when determining the payment, however, as can be seen from the Table, the standard rates for persons eligible for the nationwide family allowance are typically lower.
} 
Table 1: Parameters of the prevailing and new welfare systems, and of the alternative reform proposal

\begin{tabular}{|c|c|c|c|c|c|c|}
\hline & & singles & $\begin{array}{l}\text { household } \\
\text { heads }\end{array}$ & $\begin{array}{l}\text { not house- } \\
\text { hold head }\end{array}$ & $\begin{array}{l}\text { not house- } \\
\text { hold head } \\
\text { and receiv- } \\
\text { ing family } \\
\text { allowance }\end{array}$ & UA \\
\hline \multirow{9}{*}{ 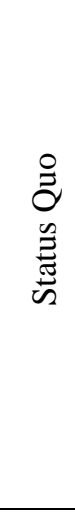 } & Burgenland & 744.0 & 558.0 & 558.0 & 166.8 & \multirow{14}{*}{ 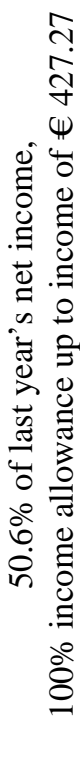 } \\
\hline & Carinthia & $731.1^{1)}$ & 635.0 & 635.0 & 177.1 & \\
\hline & Lower Austria & 731.6 & 654.8 & 348.1 & 170.9 & \\
\hline & Upper Austria ${ }^{5)}$ & 1000.5 & 807.1 & 595.4 & 189.0 & \\
\hline & Salzburg ${ }^{2)}$ & 841.9 & 673.3 & 497.7 & 181.4 & \\
\hline & Styria & 888.1 & 707.7 & 514.1 & 197.2 & \\
\hline & Tyrol $^{5)}$ & 846.2 & 652.4 & 510.0 & 181.7 & \\
\hline & Vorarlberg $^{5)}$ & 924.1 & 702.0 & 518.5 & 187.4 & \\
\hline & Vienna & $776.0^{1)}$ & 522.5 & 522.5 & 137.0 & \\
\hline \multirow{5}{*}{$\sum_{\infty}^{\infty}$} & Standard rate $(€)$ & 744.0 & 558.0 & 558.0 & 133.9 & \\
\hline & Income allowance rate & \multicolumn{4}{|c|}{$15 \%$} & \\
\hline & Minimum income allowance (€) & \multicolumn{4}{|c|}{52.1} & \\
\hline & Maximum income allowance (€) & \multicolumn{4}{|c|}{126.5} & \\
\hline & Cut if not employed & \multicolumn{4}{|c|}{ Up to $50 \%$ if repeatedly unwilling to take up job } & \\
\hline \multirow{7}{*}{ 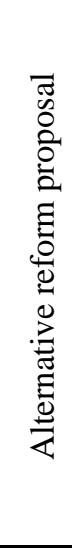 } & Standard rate $(€)$ & 744.0 & 558.0 & 558.0 & 133.9 & \multirow{7}{*}{ 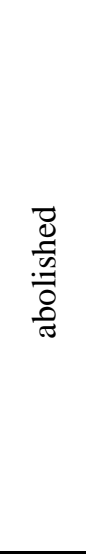 } \\
\hline & Income allowance rate & \multicolumn{4}{|c|}{$15 \%$} & \\
\hline & Minimum income allowance $(€)$ & \multicolumn{4}{|c|}{ - } & \\
\hline & Maximum income allowance $(€)$ & \multirow{2}{*}{\multicolumn{4}{|c|}{ oyable }} & \\
\hline & Cut if not employed & & & & & \\
\hline & & $60 \%$ & SSC if wor & ig more thar & 5 hours & \\
\hline & SS contribution subsidy & $\begin{array}{r}\text { Increme } \\
\text { Introduc } \\
\text { co } \\
\end{array}$ & $\begin{array}{l}\text { \% if workin } \\
\text { l decline if } \\
\text { n of SSC for } \\
\text { limit („Ger }\end{array}$ & $\begin{array}{l}\text { nore than } 30 \\
\text { ome betwee } \\
500 \\
\text { comes belo } \\
\text { sfügigkeits }\end{array}$ & $\begin{array}{l}\text { ours } \\
€ 800 \text { and } € \\
\text { marginal in- } \\
\text { nze“) }\end{array}$ & \\
\hline \multicolumn{7}{|c|}{${ }^{1)}$ This rate also applies for single parents } \\
\hline \multicolumn{7}{|c|}{ 2) Income allowance of $€ 134$ for fulltime and $€ 67$ for part-time employment } \\
\hline \multicolumn{7}{|c|}{$\begin{array}{l}\text { Note: UA and SA amounts are adjusted to } 12 \text { monthly payments. They include the standard rate as well as } \\
\text { cost for renting and, if applicable, heating. In case full renting costs are paid, we assume they are the median } \\
\text { of the observed costs. }\end{array}$} \\
\hline
\end{tabular}

\footnotetext{
${ }^{6}$ If the person receiving SA owns a house, for example, she will be allowed to further use it, however, the authorities will claim ownership.
} 


\subsection{The new welfare system (“Bedarfsorientierte Mindestsicherung”)}

By the end of this/beginning of next year, the current social assistance (SA) system will be replaced by a "needs-based minimum benefit” (“Bedarfsorientierte Mindestsicherung”, BMS), although the generous allowances for income from marginal employment of recipients of unemployment benefit and unemployment assistance payments will stay in place. We will see later that this poses a problem since keeping UA and UB weakens labor supply incentives. Nonetheless, BMS differs in many important aspects from the current SA system.

First, there are different standard rates including coverage of renting as well as heating (see Table 1). The BMS standard rates are equal to the rates for minimum pensions ("Ausgleichszulagenpensionen”) in Austria. Single individuals will receive $€ 744$ and couples $€$ 1,116 per month. Unlike in the prevailing system, this will be paid 12 rather than 14 times a year. However, these standard rates are minimum rates and several federal states will offer surcharges for the standard transfer rates and keep some irregular benefits, e.g. for clothing ${ }^{7}$. Moreover, the federal states agreed to guarantee the prevailing amount of social assistance to those who currently receive it. Thus, if BMS were lower than SA, which Table 1 shows to be the case for several states and household types, people receiving SA when BMS is introduced will be paid the difference such that their transfer income will not be reduced. Thus, the longterm impact of the reform will differ significantly from its short-term impact due to this "grandfathering” of SA entitlements.

Second, there is an asset allowance of $€ 3,750$ such that financial assets below this amount do not need to be exploited prior to receiving the transfer.

Third, and most importantly for our purposes, if a benefit recipient takes up a job, 15\% of her income, but at least $€ 52.1$ and at most $€ 126.5$ will not be deducted from the transfer.

Fourth, if transfer recipients are unwilling to take up a job, although they repeatedly have received job offers, the transfer will be cut by up to 50\%. Up until now, there is no strict guidance of this procedure and we thus cannot predict how often it will be applied in practice.

Fifth, as noted already above, BMS recipients will, unlike SA recipients, be supervised by the unemployment agency, which should facilitate bringing them together with potential employers.

Sixth, BMS recipients will have health insurance while SA recipients are currently entitled to free medical treatment by making use of special certificates ("Sozialhilfekranken-

\footnotetext{
${ }^{7}$ At the time of writing (September 2010), decisions on the exact amounts of transfer rates are still pending in six of nine federal states.
} 
scheine”). Health insurance for BMS recipients will be financed by paying a fraction of 5.1\% of the standard rates to the federal health insurance fund.

\subsection{An alternative reform proposal}

The alternative reform proposal is related to the needs-based minimum benefit system (“BMS”) by its standard rates for singles, household heads, spouses and children as well as the income allowance rates, but differs in three important ways.

First, unemployment assistance ("Notstandshilfe", UA) is merged with SA under the alternative reform proposal. This implies that if someone is still unemployed after the unemployment insurance payment (“Arbeitslosengeld”, UB) has expired, she will have to rely on social assistance with the BMS' standard rates and means-testing procedure. This will lead to income losses for persons who had high unemployment benefits and who profited from the limited means testing regulations of UA. Abolishment of UA and removing the generous implicit subsidies for marginal employment is, as we will see later, for improving financial incentives to work longer hours and earn wage income above the marginal social security threshold. Furthermore, since UA is a means-tested social transfer, there is no obvious reason for linking its amount to the individual UB level.

Second, while the income allowance rate of $15 \%$ is retained, the minimum allowance of $€ 52.1$ and the maximum allowance of $€ 126.5$ are abolished. This makes the budget constraints steeper for wage incomes below $€ 347.3$ per month ( $=€ 52.1 / 0.15)$ and above $€ 843.3$ (= $€ 126.5 / 0.15)$ and thus improves financial work incentives. The reform proposal also removes the implicit subsidy for marginal employment and subjects yearly wage incomes below the marginal employment limit to social security contributions. Instead, social security contributions on regular employment at low wages will be subsidized. The subsidy rate depends on hours worked: If employment exceeds 15 hours a week, $60 \%$ of social security contributions will be refunded; if working hours are more than 30 hours a week, social security contributions will be fully refunded. The full amount of this subsidy will be granted if monthly gross earnings are below $€ 800^{8}$. For higher earnings, the subsidy rates of $60 \%$ or $100 \%$ will be incrementally reduced below an amount of monthly gross earnings of $€ 1,500$. For monthly earnings above $€ 1,500$, no subsidy of social security contributions applies anymore.

Finally, the proposed welfare reform features transfer cutbacks of $15 \%$ of the respective standard rate for people who are employable, but are working less than 15 hours a week. We 
define being employable as being younger than 65 and not taking care of children younger than 14 or other household members who need care. Thus, there is no transfer cutback for single parents or for single individuals who take care of, e.g., elderly relatives. Also, there is no cutback for couples with children as long as one partner works for more than 15 hours per week. However, if a couple has no children, both spouses will have to work longer than 15 hours a week in order to prevent the transfer cutback.

Thus, the reform proposal contains elements of both the needs-based BMS and welfare reforms already implemented or discussed in other EU member states. It rewards regular employment of people with low earnings potential within the social security system and removes the prevailing implicit subsidies of both marginal employment and working a few hours while living on means-tested unemployment assistance.

\section{Empirical methodology}

Our empirical analysis of the labor supply and income effects of the planned and proposed welfare reforms described in the previous section is based on the behavioral mircosimulation model ATTM (Austrian Tax-Transfer Model, see Steiner and Wakolbinger, 2009). ATTM incorporates a comprehensive image of the various components of the Austrian taxtransfer system including all the interactions among them at the level of individual households. ATTM is based on data from the EU-SILC (Survey on Income and Living Conditions) survey conducted by Statistik Austria (2006). This representative sample of 6,028 Austrian households includes data on sociodemographic characteristics, household incomes as well as current employment status and hours worked of adult household members. For a detailed data description, see Steiner and Wakolbinger (2009). Using ATTM and detailed household data, we can derive net household incomes under both the current and alternative welfare systems accounting for changes in household labor supply induced by these reforms. Here, we only simulate the short-term effects of the reforms accounting for the "grandfathering" of SA entitlements described in Section 0 above, and do not account for longer-term effects when the new system is fully phased in.

The estimation of the labor supply effects of the two analyzed welfare reforms is based on a structural household labor supply model as suggested by van Soest (1995) and applied by Steiner et al. (2008), among others. The discrete-choice model implemented in ATTM as-

\footnotetext{
${ }^{8}$ In the Austrian system, someone who earns a monthly wage of $€ 800$ would each month receive a payment of $€ 685.71$ and two extra payments (holiday and Christmas allowance) of $€ 685.71$ each.
} 
sumes that the observed households can choose between $J$ working hour categories. One of these categories typically represents unemployment, i.e. zero working hours. For estimating the labor supply impacts presented in the following section, we chose to specify six working hours categories for women (0,1-12, 13-20, 21-34, 35-40 and more than 40 hours) and only four for men (0, 1-20, 21-40 and more than 40 hours). The estimations are performed separately for male and female singles (950 and 976 households respectively), women with inflexible spouse (778 households), men with inflexible spouse (225 households) and couple households where both partners are flexible (1703 households).

A decisive advantage of discrete-choice labor supply models is that non-linearities in household budget constraints can be modeled much easier than using more traditional specifications of continuous labor supply models. Another important advantage is that they allow, in combination with a microsimulation model like ATTM, to account for the endogeneity of net household income in a consistent way. This is achieved by calculating for each household and each of the discrete choices (hours categories) a counterfactual net household income using ATTM. Estimation of hourly wages of currently non-employed people is based on the twostep Heckman (1979) procedure which accounts for potential selection bias with respect to the individual's employment decision. ${ }^{9}$ Under the assumption of constant gross hourly wages across labor supply categories, there is a corresponding level of disposable income for each household $i$ choosing hour category $j$.

Since the current version of ATTM does not model the household's savings decision, disposable income corresponds to the household's consumption level, $C_{i j}$. The household utility function therefore is

$$
V_{i j}=U\left(L f_{i j}, L m_{i j}, C_{i j}, Z_{i}\right)+\varepsilon_{i}
$$

which assigns for each possible choice $j$ of hour-categories a utility level $V$ depending on the leisure of the female and male partner in household $i, L f_{i j}$ and $L m_{i j}$, their disposable income or consumption $C_{i j}$, some household characteristics $Z_{i}$ and an error term $\varepsilon_{i}$.

We assume a quadratic specification of the deterministic part of the utility function as

\footnotetext{
${ }^{9}$ In ATTM, estimation is performed separately for women and men. In the first step, the probability of being employed is estimated by a binary probit model with marital status, the number and age of children a dummy indicating whether a person has ever been employed as well as household income included as explanatory variables in addition to the variables also included in the wage regression. In the second-step wage regression estimated on the sub-sample of currently employed people and including the selection term from the first stage, the other explanatory variables are age and age squared, dummies for educational attainment and vocational training,
} 


$$
\begin{aligned}
& U_{i j}=\beta_{1} C_{i j}+\beta_{2} C_{i j}^{2}+\beta_{3} L f_{i j}+\beta_{4} L m_{i j}+\beta_{5} L f_{i j}^{2}+\beta_{6} L m_{i j}^{2} \\
& +\beta_{7} C_{i j} L f_{i j}+\beta_{8} C_{i j} L m_{i j}+\beta_{9} L f_{i j} L m_{i j}
\end{aligned} .
$$

Of course, we would expect the marginal utility to be positive with respect to income and leisure of both spouses, and decreasing in the level of income and leisure consumed. ${ }^{10}$ Theory does not, however, imply restrictions on the sign of the marginal utility of one spouse's leisure to changes in the level of the other spouse's leisure. This specification of the utility function does not restrict substitution between leisure and consumption to be independent of the utility level or income. In fact, elasticities may vary freely across households, depending on the level of income, the level of leisure or working hours of the two spouses, and household composition. The specification of the utility function allows for varying household preferences by employing "taste shifters" which affect the coefficients of the linear income and leisure terms, i.e.:

$$
\begin{aligned}
& \beta_{1}=\alpha_{0}^{C}+X_{1}^{\prime} \alpha_{1}^{C} \\
& \beta_{3}=\alpha_{0}^{L f}+X_{2}^{\prime} \alpha_{1}^{L f} \\
& \beta_{4}=\alpha_{0}^{L m}+X_{3}^{\prime} \alpha_{1}^{L m}
\end{aligned}
$$

$X_{1}, X_{2}$ and $X_{3}$ are column vectors including sociodemographic characteristics like age, number and age of children, disability indicators and whether the observed person is Austrian citizen, and the $\alpha$ 's are vectors of coefficients which are jointly estimated with the $\beta$ 's from the utility function above.

If the error terms $\varepsilon_{i}$ are assumed to be independently and identically distributed across hour categories and households according to the Extreme-Value type I (EVI) distribution, the probability that alternative $k$ is chosen by household $i$ is given by a conditional logit model (McFadden, 1974):

$$
P_{i k}=\operatorname{Pr}\left(V_{i k}>V_{i j}, \forall j=1 \ldots J\right)=\frac{\exp \left(U_{i k}\right)}{\sum_{j=1}^{J} \exp \left(U_{i k}\right)}, k \in J .
$$

The decision rule is simple: Alternative $k$ is chosen if the net income and the level of leisure under this alternative yield a utility index which is greater than that for any other alterna-

and variables describing an individual's previous labor market history, and dummy variables for region, industry and firm size.

${ }^{10}$ The utility function for a single household is a special case of the above equation, with $\beta_{9}$, and, depending on whether the household head is female or male, the respective coefficients on male and female leisure being restricted to zero. 
tive. This specification implies that individuals and households are not restricted in their choice of hours. Estimation results for the labor supply are reported in the Appendix. Based on these estimates, the expected values of individual working hours and participation rates can be derived under the prevailing and alternative welfare systems.

\section{Simulation results}

\subsection{Budget constraints}

We first present for "representative" households plots of monthly household income against the number of hours worked per week under the alternative welfare systems presented above. These figures provide a clear image of the financial incentives to increase labor supply (i.e. the number of working hours) under each welfare system. The steeper the budget constraint, the more an additional working hour pays off and the higher we expect the incentives to increase labor supply to be.

\section{Singles without children}

The upper part of Figure 2 shows the budget constraints for singles with an hourly wage of $€ 10.7$ (the $25^{\text {th }}$ percentile of the wage distribution of both genders) who are, in the prevailing system, entitled to receive unemployment assistance. This means that they have paid unemployment insurance payments prior to unemployment. We assume that the individual whose budget constraint is shown has worked for 40 hours per week before becoming unemployed at the given hourly wage. If she had worked less, the unemployment assistance would be lower.

Figure 2 a) shows that for the representative individual, the prevailing system offers high incentives to work around 9 hours. If the individual would work more than that, she would lose the unemployment benefit and her income would thus decrease. To be more specific, her income would fall back to the prevailing social assistance standard rates. At around 30 working hours per week, this individual would achieve the income level she generated with only 9 working hours.

Moreover, the figure also shows that the planned system ("BMS”) would not change this structure. Due to the more generous income allowance rates, net income generated by working from 10 to around 22 hours per week would slightly increase. However, the peak in the budget constraint at 9 working hours would not disappear, since with introduction of BMS, the unemployment assistance (UA) system still prevails. Thus, we expect that within the new system, the incentives to increase labor supply will hardly improve. 
Within the system alternative system, however, working less than 15 hours is punished by a transfer cutback of 15\%, while working longer than 15 hours is rewarded by a subsidy of $75 \%$ of the social security contributions. Moreover, with removal of UA, the incentivedistorting peak at 9 working hours vanishes. Thus, net income is strictly increasing in working hours, and we expect labor supply to increase.

Figure 2: Budget constraints of singles without children entitled to

a) unemployment assistance

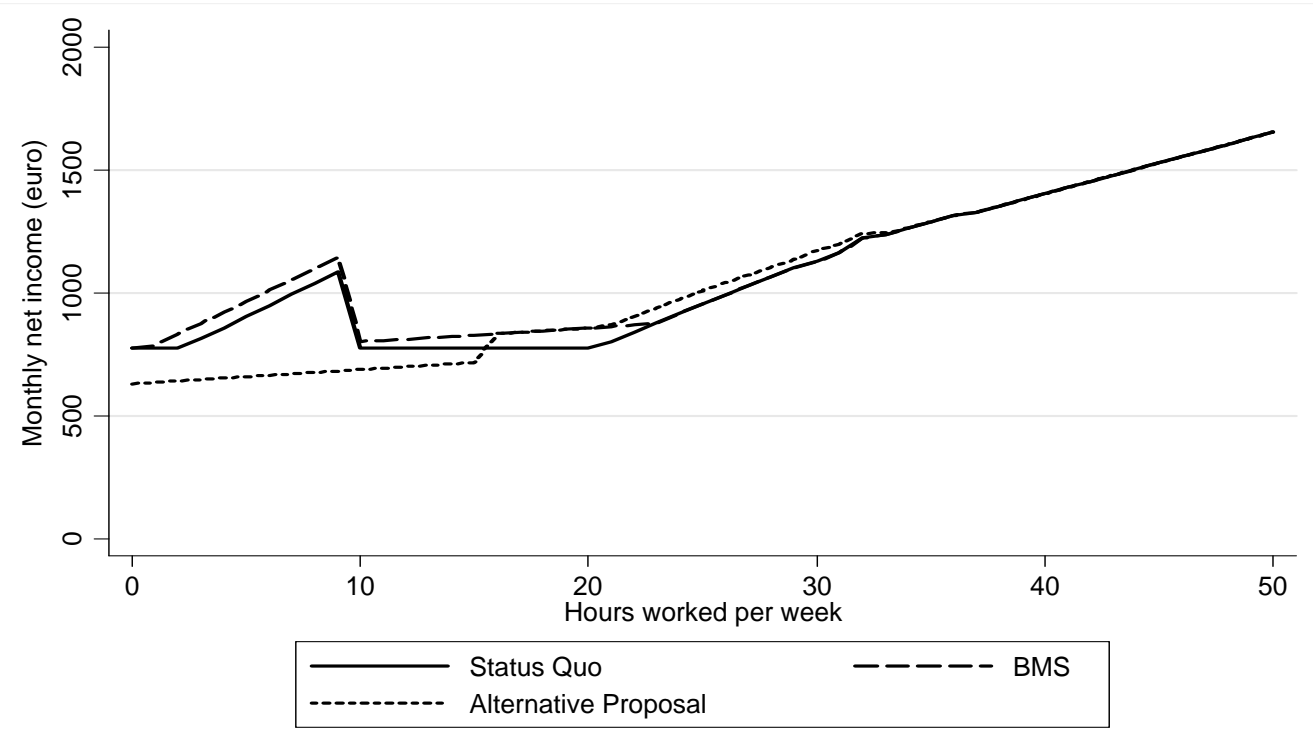

b) social assistance

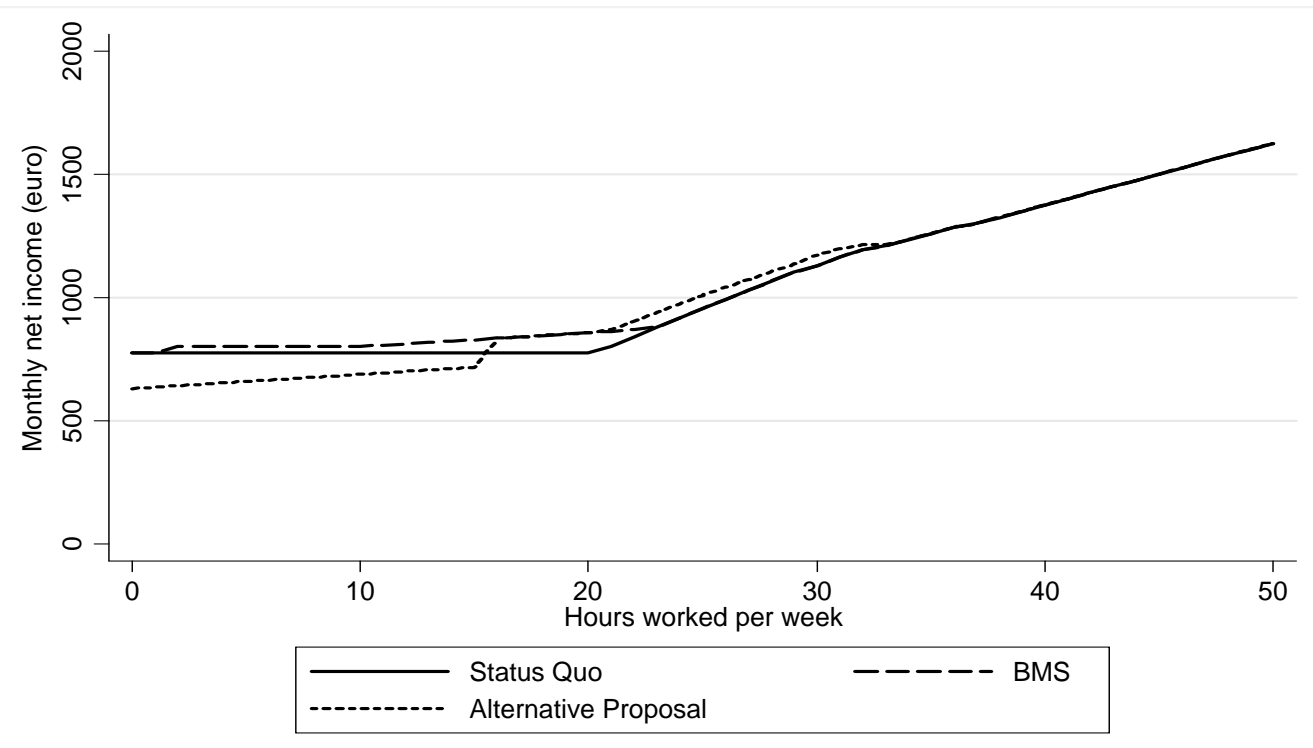

Source: ATTM

Note: We assume an hourly wage of $€ 10.7$, which is the $25^{\text {th }}$ percentile of the observed hourly wages (both genders). For the amount of the unemployment assistance payment we assume that the person has been employed for 40 hours per week prior to unemployment. For social assistance we assume that the person is not entitled to unemployment assistance. 
The lower part of Figure 2 shows the budget constraints for a single with no children who is not entitled to receive unemployment benefits. Here, we expect that an increase of labor supply which the system we propose would bring about will not be as big as for individuals entitled to unemployment assistance. However, there should still be an increase because, as noted already, our system punishes low working hours and rewards high working hours, and the budget constraint within our system is strictly increasing in the number of working hours.

We expect the introduction of BMS, which includes an income allowance of $15 \%$, to increase labor supply of singles without children entitled to social assistance. Note, however, that because of the minimum income allowance of $€ 52.1$, the income generated with around three working hours does not differ from the income generated with 10 working hours a week.

\section{Singles with children}

In Figure 3 we plot the budget constraints for singles with two children. Again, we assume their hourly wage to be the $25^{\text {th }}$ percentile of the wage distribution of both genders (€ 10.7). Whether or not a single with two children was entitled to receive unemployment assistance, her income is considerably higher than that of a single without children. This is due to the fairly generous Austrian family allowances which are paid without any meanstesting. If a single with two children was in the prevailing system entitled to unemployment assistance (Figure 3), the household income would peak at nine working hours (see the same pattern in Figure 1 and Figure 2) and fall with more than 9 hours back to the level of the SA standard rate. Again, the household budgets generated with 9 and 30 working hours are equal. While the introduction of BMS would not remove the peak in the budget constraint, it would be removed if the reform proposal was introduced. We would expect BMS to have no impact on labor supply, while we expect an increase in labor supply under the alternative proposal. Note that there is no transfer cutback if the individual works less than 15 hours a week in this case because single parents are not defined as being employable.

For single parents entitled to social assistance, we expect the effects on the budget constraint which BMS would bring about are not much different from the effects the alternative proposal would trigger. As can be seen from Figure 3, the budget constraints overlap for workloads between 10 and 25 hours per week. For people who work less than 10 hours, BMS would provide slightly more income, while those who work more than 25 hours are made better off in the system we propose. Thus, labor supply should be slightly higher for the alternative proposal. In general, however, both BMS and the alternative proposal should bring 
about higher labor supply than the prevailing system does, because both BMS and the alternative proposal reward employment with an income allowance of $15 \%$.

Figure 3: Budget constraints of singles with two children entitled to

a) unemployment assistance

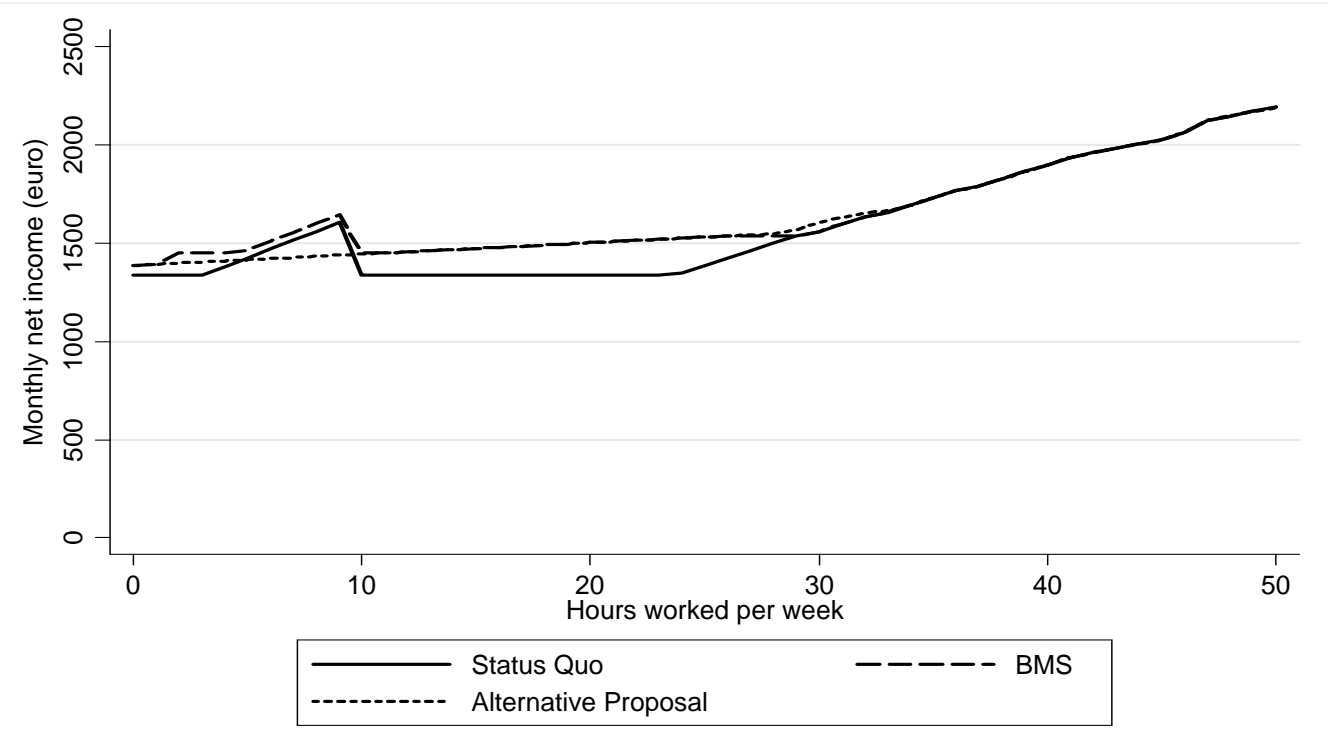

b) social assistance

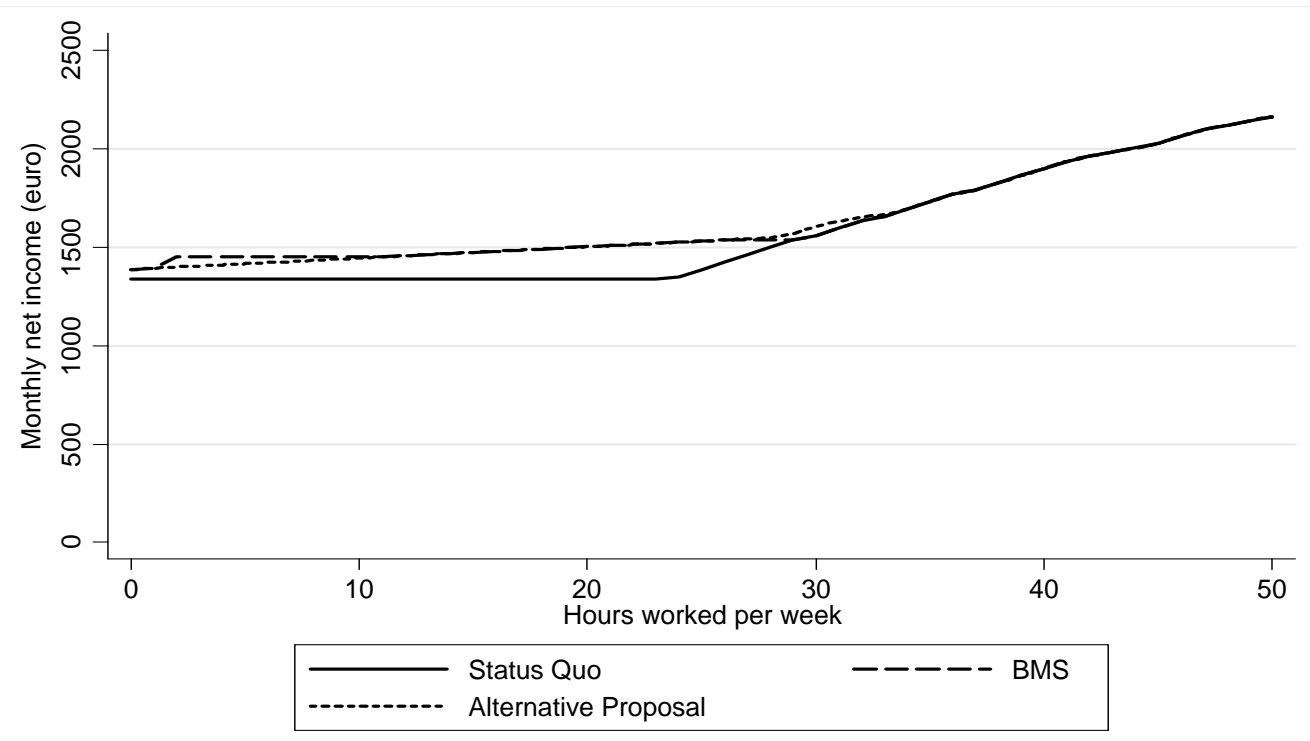

Source: ATTM

Note: We assume an hourly wage of $€ 10.7$, which is the 25th percentile of the observed hourly wages (both genders), and that this person is not entitled to unemployment assistance and has therefore to rely on social assistance. 


\section{Couple households}

Figure 4 shows the budget constraints for a couple with two children, where one spouse is out of the labor force and the other has an hourly wage of $€ 12.23$, which is the $25^{\text {th }}$ percentile of the distribution of observed male hourly wages. For such a household, it is irrelevant whether the wage-earner is entitled to receive unemployment- or social assistance within the prevailing system, since the social assistance standard rates are higher than the maximum amount of unemployment assistance ${ }^{11}$. Figure 4 shows that the single-earner receiving the $25^{\text {th }}$ percentile of hourly wages would have to work more than 30 hours per week in order to exceed the social assistance standard rate plus the family allowance. Within the BMS system, the wage-earner could increase income although receiving the benefit because of the income allowance of $15 \%$. Within the system we propose, however, working less than 15 hours per week would be punished by a transfer cutback of 15\%, while working more than 15 hours would be rewarded by the subsidy social security contributions. We thus expect labor supply of one-earner couples to be highest within the system we propose, and labor supply within the BMS system to be higher than within the prevailing system.

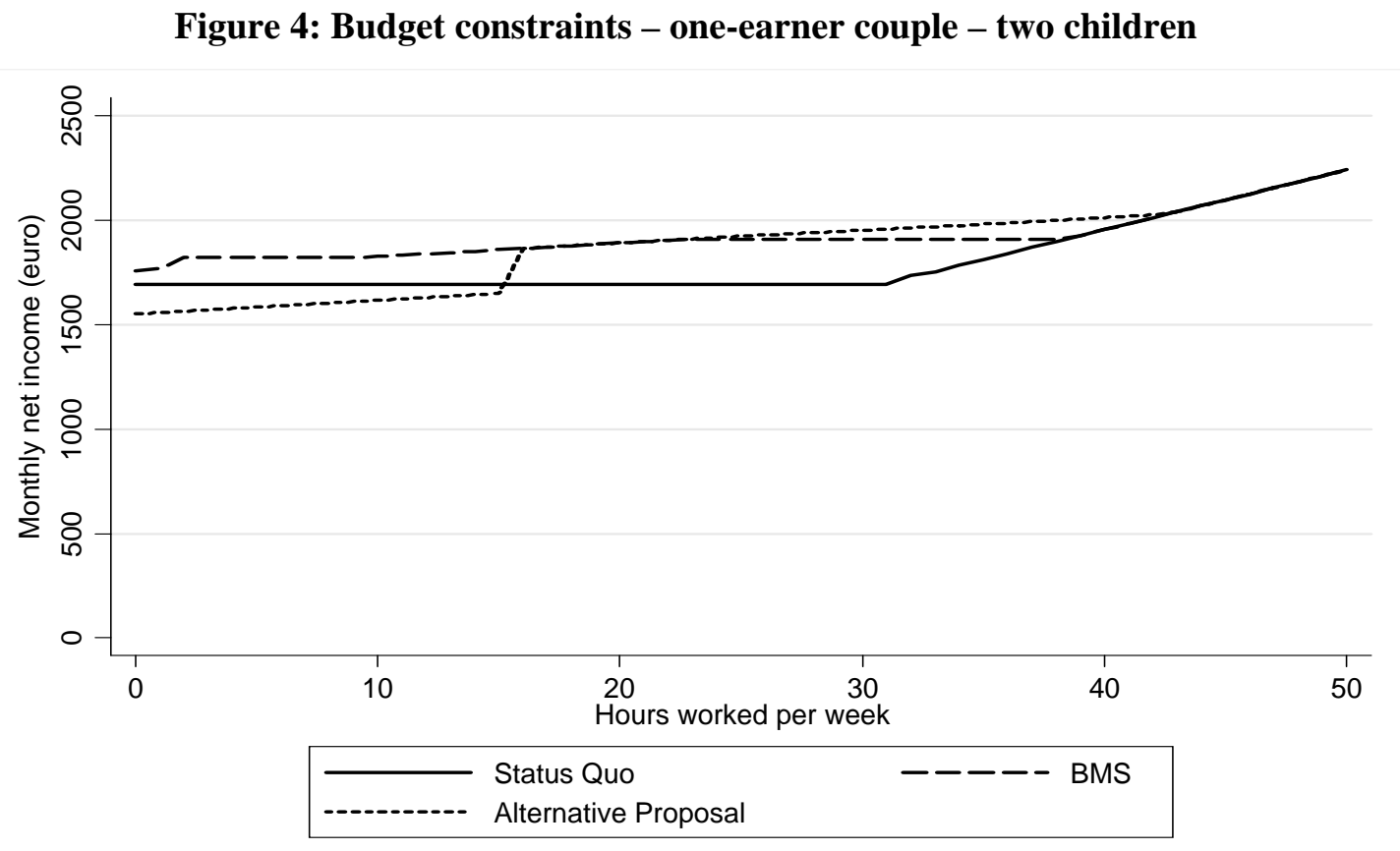

Source: ATTM

Note: We assume one spouse to be out of the labor force and the other one to have an hourly wage of $€ 12.23$, which is the $25^{\text {th }}$ percentile of the observed male hourly wages. This person varies his labor supply as depicted in the Figure.

\footnotetext{
${ }^{11}$ If the couple had exploitable assets and was therefore reluctant to apply for social assistance, the social assistance standard rates would not apply and the budget constraint would be different.
} 


\subsection{Labor supply and participation rates}

Table 2 shows the estimated changes in labor market participation rates, hours worked and full-time equivalents induced by the introduction of the BMS or the alternative reform proposal. As shown by the table, the estimated change of individual participation rates is slightly negative (-0.038 percentage points) for the BMS and positive (0.467 percentage points) for the alternative reform proposal. For this latter proposal, participation rates increase, on average, for both women and men living in couples as well as for female and male singles. For the BMS, female singles are the only group for whom we estimate a small increase in labor market participation, on average, while estimated effects are negative for spouses as well as male singles.

Estimated changes in working hours show the same pattern. For the introduction of BMS, the mean change is -0.108 percent, compared to 0.942 percent estimated for the alternative reform proposal. Note however that estimated standard errors of these estimates are fairly large.

Estimated individual changes in labor force participation rates and hours worked result, on average, in an expected reduction in labor supply of about 600 full-time equivalents under BMS. In contrast, under the alternative reform proposal total labor supply would increase by about 13,000 full-time equivalents, of which $43 \%$ stems from increasing labor supply of women living in couples.

Table 2: Simulated changes in labor supply, participation rates and full-time equivalents

\begin{tabular}{lccccc}
\hline \hline & \multicolumn{2}{c}{ Couples } & \multicolumn{2}{c}{ Singles } & \multirow{2}{*}{ Total } \\
& Women & Men & Women & Men \\
& \multicolumn{7}{c}{ hours worked (in percent) } \\
\hline \multirow{3}{*}{ BMS } & -0.197 & -0.158 & 0.094 & -0.016 & -0.108 \\
& $(-0.025)$ & $(-0.020)$ & $(0.013)$ & $(0.011)$ & $(-0.011)$ \\
Alternative Proposal & 2.08 & 0.688 & 0.615 & 0.061 & 0.942 \\
& $(0.123)$ & $(0.047)$ & $(0.071)$ & $(0.045)$ & $(0.050)$ \\
& & participation rates (in percentage points) & \\
BMS & -0.087 & -0.047 & 0.048 & -0.016 & -0.038 \\
& $(0.010)$ & $(0.009)$ & $(0.007)$ & $(0.007)$ & $(-0.005)$ \\
Alternative Proposal & 0.868 & 0.611 & 0.469 & 0.086 & 0.467 \\
& $(0.050)$ & $(0.035)$ & $(0.052)$ & $(0.029)$ & $(0.022)$ \\
BMS & \multicolumn{7}{c}{ full-time equivalents } & \\
Alternative Proposal & -445 & -508 & 479 & -115 & -589 \\
\hline \hline
\end{tabular}

* standard errors in parentheses

The pattern shown by Table 2 largely confirms what is expected from looking at the budget constraints shown in Section 4.1. Estimated labor supply effects under the two reforms 
increases are consistent with stronger financial incentives to increase working hours under the alternative reform proposal compared to the BMS. However, the simulated reduction in labor supply under the BMS was not to be expected from the implied budget constraints shown for “representative” households in Section 4.1.

\subsection{Distributional effects}

In Table 3 we show simulated distributional effects of the BMS and the alternative reform proposal on monthly net equivalence income. We have divided the sample into four categories defined by net equivalence income classes (NEIC). Out of a total population of eight million people, 450,000 persons belong to the lowest NEIC; they have less than $50 \%$ of the average monthly net equivalence income of $€ 1,833$. Roughly less than 4.5 million people belong to the second NEIC (50-100\% of average monthly net equivalence income), 2.4 million to the third NEIC (100-150\%) and 740,000 to the highest (> 150\%).

Table 3: Distributional effects of the BMS and the alternative proposal

\begin{tabular}{|c|c|c|c|c|c|}
\hline & \multirow[b]{2}{*}{ NEIC } & \multicolumn{2}{|c|}{ more income } & \multicolumn{2}{|c|}{ less income } \\
\hline & & $\begin{array}{c}\text { affected } \\
\text { persons }\end{array}$ & $\begin{array}{c}\text { average } \\
\text { gain }\end{array}$ & $\begin{array}{l}\text { affected } \\
\text { persons }\end{array}$ & $\begin{array}{c}\text { average } \\
\text { loss }\end{array}$ \\
\hline & \multicolumn{5}{|c|}{ without labor supply effects } \\
\hline \multirow{5}{*}{$\sum_{\infty}^{\infty}$} & $<50 \%$ & 77,226 & 97.5 & & \\
\hline & $50-100 \%$ & 19,851 & 11.8 & & \\
\hline & $100-150 \%$ & 819 & 2.8 & & \\
\hline & $>150 \%$ & & & & \\
\hline & Total & 97,896 & & & \\
\hline \multirow{6}{*}{ 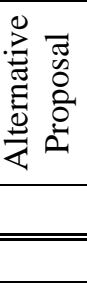 } & $<50 \%$ & 65,244 & 101.5 & 16,901 & -71.5 \\
\hline & $50-100 \%$ & 35,065 & 42.2 & 51,739 & -110.9 \\
\hline & $100-150 \%$ & 7,101 & 35.8 & 9,082 & -92.7 \\
\hline & $>150 \%$ & 3,832 & 24.9 & 1,307 & -118.4 \\
\hline & Total & 111,242 & & 79,029 & \\
\hline & \multicolumn{5}{|c|}{ with labor supply effects } \\
\hline \multirow{5}{*}{$\sum_{\infty}^{\infty}$} & $<50 \%$ & 78,303 & 96.2 & 2,227 & -8.9 \\
\hline & $50-100 \%$ & 36,170 & 6.8 & 24,174 & -1.7 \\
\hline & $100-150 \%$ & 6,669 & 0.2 & 4,833 & -0.7 \\
\hline & $>150 \%$ & 911 & 0.0 & 3,913 & -0.1 \\
\hline & Total & 122,053 & & 35,147 & \\
\hline \multirow{5}{*}{ 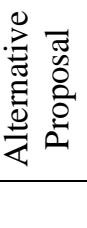 } & $<50 \%$ & 67,955 & 97.9 & 14,190 & -82.6 \\
\hline & $50-100 \%$ & 34,455 & 57.5 & 52,349 & -112.6 \\
\hline & $100-150 \%$ & 7,437 & 67.6 & 8,746 & -121.5 \\
\hline & $>150 \%$ & 3,832 & 38.4 & 1,307 & -115.9 \\
\hline & Total & 113,679 & & 76,592 & \\
\hline
\end{tabular}

Table 3 shows how many persons of each NEIC will be, respectively, positively and negatively affected by the reforms. In addition, the average estimated monetary gain or loss is 
reported. Without consideration of potential changes of labor supply, the introduction of BMS would not trigger any income losses since the prevailing amount of social assistance is guaranteed by the federal states. Net equivalence income of 77,000 persons belonging to the lowest NEIC will increase by slightly less than $€ 100$ per month, on average. In the second and third highest NEIC, less persons are affected, and the monetary gains are only about $€ 12$ and $€ 3$, respectively. Allowing for labor supply shifts does not change these effects much. However, since the estimated elasticities are low and negative, some 35,000 persons are estimated to incur slight negative monetary effects.

If the alternative reform proposal came into place, slightly more persons would see positive income effects. Apart from the lowest NEIC, these positive income effects would be more substantial than under the planned reform. This is due to more generous allowances of employment income. However, almost 80,000 persons would be negatively affected, and for these people the average loss would be quite substantial. In the lowest NEIC; the negative effect is somewhat weaker, while in the other NEICs, the estimated negative monetary effects on net equivalence income exceed $€ 100$ per month. To a large extent, those negative effects are due to the replacement of unemployment assistance by a reformed social assistance which is lower and has less generous allowances for spouses’ income and assets.

\subsection{Fiscal effects}

Table 4 shows the simulated fiscal effects of the introduction of BMS and the alternative reform proposal. Introducing BMS would provoke no change in income tax and social security contributions. Moreover, the amount of paid unemployment assistance would not change since it is planned to retain the prevailing system of unemployment benefits and assistance when BMS is introduced. Social assistance payments would rise by $€ 295 \mathrm{mn}$. (assuming a $100 \%$ take-up rate in both the BMS as well as the prevailing system). Although the BMS standard transfer rates are lower than the standard rates of the prevailing system for the majority of federal states (see Table 4), social assistance payments would rise. One reason for this is that the federal states agreed to prevent income losses of transfer recipients and to pay the difference if the transfer in the BMS system was lower than in the existing one. Another reason lies in the income allowance rates, which leave some income unconsidered when determining the transfer rate.

The introduction of the alternative reform proposal would slightly increase income tax revenues due to increased labor supply, while social security contribution revenues would shrink by $€ 383 \mathrm{mn}$. because of the SSC-subsidy for wage-earners who work more than 15 
hours per week. Unemployment assistance payments would become obsolete because this system is to be abolished, which would reduce expenditures by $€ 275.8 \mathrm{mn}$. However, social assistance payments would rise by $€ 36 \mathrm{mn}$. due to higher transfers paid to those who received social assistance under the current system. Table 4 shows that, due to the positive labor supply and employment effects, the introduction of the alternative reform proposal is estimated to improve the total budget by a small amount of $€ 67 \mathrm{mn}$.

Table 4: Fiscal effects of the BMS and the alternative reform proposal, in mn. $€$

\begin{tabular}{lccccc}
\hline & \multirow{2}{*}{ Status Quo } & \multicolumn{2}{c}{ BMS } & \multicolumn{2}{c}{ Alternative reform proposal } \\
& & without LS & with LS & without LS & with LS \\
\hline Income Tax & $23,564.3$ & 0.0 & -4.5 & 0.0 & 21.2 \\
SS Contributions & $39,018.6$ & 0.0 & -6.6 & -383.0 & -236.0 \\
Unemployment assistance & -965.3 & -7.5 & -14.7 & 275.8 & 313.0 \\
Social assistance & -441.2 & -139.1 & -141.7 & -36.0 & -30.6 \\
\hline Total & & -146.6 & -167.5 & -143.2 & 67.6 \\
\hline \hline
\end{tabular}

\section{Conclusion}

By the end of this/beginning of next year the Austrian government and the federal states plan to introduce a needs-based minimum benefit system ("Bedarfsorientierte Mindestsicherung”, BMS) which will replace the prevailing system of social assistance. The main advantages of BMS are seen in harmonizing the different transfer rates (each federal state has different rates), in inducing re-entry to the labor market by supervising transfer recipients by the unemployment agency and in providing incentives for taking up work by introducing a small allowance for earned income for recipients of BMS. In the existing system, there are very little work incentives for recipients of social assistance because each Euro of additional wage income reduces the transfer by one Euro.

Our simulation results based on the Austrian Tax-Transfer Model ATTM show, however, that the introduction of BMS will not increase labor supply of transfer recipients. By analyzing the budget constraints of various model households (singles without children, singles with children, one-earner couples with children) we show that introducing BMS does not improve labor supply incentives because even after the introduction of BMS the system of unemployment benefits and unemployment assistance will still prevail. This system still features generous and implicit subsidies for marginal employment as well as large transfer cutbacks if wage income exceeds the marginal income limit (“Geringfügigkeitsgrenze”). Furthermore, for people receiving SA when BMS is introduced their transfer income will not be reduced, and this grandfathering” of SA entitlements is also modeled in our simulation. Thus, the long-term 
impact of the reform will differ significantly from its short-term impact when the new system applies to all recipients of SA and means-tested out-of-work benefits, respectively.

We have also analyzed an alternative reform proposal which combines the same standard rates and an income allowance rate as BMS but in addition merges unemployment assistance and social assistance, abolishes the implicit subsidy of marginal employment, and imposes a transfer cutback if employable individuals work less than 15 hours per week. If employees work more than that, however, they are granted a subsidy of their social security contributions which is gradually reduced as income increases. This proposal is calibrated to make it revenue neutral without accounting for potential labor supply effects. In fact, our simulations show that it will yield small budgetary revenues if positive labor supply effects are taken into account. The introduction of this alternative reform proposal would increase labor supply by a total of some 13,000 full-time equivalents but almost 80,000 persons would suffer income losses under this reform, and for these people the average loss would be quite substantial. Given the structure of the current Austrian welfare system it seems fairly difficult to invent budgetary-neutral reforms which improve financial work incentives without reducing nonwork income for those currently receiving relatively high means-tested social transfers.

Our simulation results are likely to underestimate the long-term effect of the analyzed welfare reforms on labor supply and household incomes due to the "grandfathering" of SA entitlements. On the other hand, we currently do not account for incomplete take-up of means-tested transfers in our simulations, and the take-up rate may well be affected by a change of the nature of these transfers under the analyzed reforms. To account for these potentially important factors in simulations of welfare reforms is a topic for future research. 


\section{References}

AMS (2009): Leistungen des Arbeitsmarktservices - Arbeitslosengeld und Notstandshilfe. www.ams.at.

Blundell, R. (2006): Earned income tax credit policies: impact and optimality. The Adam Smith Lecture, 2005, Labour Economics 13, 423-443.

Haan, P., Steiner, V. (2007): Mehr Beschäftigung durch Subventionierung der Sozialbeiträge? Eine empirische Evaluation aktueller Reformvorschläge. Perspektiven der Wirtschaftspolitik 8, 378-88.

Heckman, J. (1979): Sample selection bias as a specification error. Econometrica 47, 153-161.

Meyer, B., Holtz-Eakin, D. (eds.) (2002), Making Work Pay: the Earned Income Tax Credit and Its Impact on American Families. Russell Sage Foundation, New York.

Müller, K.-U., Steiner, V. (2010): Would a Legal Minimum Wage Reduce Poverty? A Microsimulation Study for Germany. Journal of Income Distribution, 18 (3-4), 131-151.

OECD (2010): Main economic indicators - Principaux indicateurs économique. Volume 2010/2 - February.

Sinn, H.-W., Holzner, C., Meister, W., Ochel, W., Werding, M. (2006): Aktivierende Sozialhilfe 2006: Das Kombilohn-Modell des ifo Instituts. ifo Schnelldienst 59, 3-24.

Statistik Austria (2006): EU-Survey on Income and Living Conditions - Wave 2006. Statistik Austria, Vienna.

Statistik Austria (2009): Arbeitsmarktstatistik - 3. Quartal 2009. Mikrozensus - Arbeitskräfteerhebung. Statistik Austria, Vienna.

Steiner, V. (2004): Social Welfare Reform and the Low-Wage Labor Market in Germany: What Works and What Doesn't? Applied Economics Quarterly, 55, 57-78

Steiner, V. (2006): Subventionierung von Beschäftigung im Niedriglohnbereich - Ein Ausweg aus der Beschäftigungskrise? Wirtschaftspolitische Blätter 53, 203 - 16.

Steiner, V., Wakolbinger, F. (2009): The Austrian Tax-Transfer Model ATTM - Version 1.0. Berlin and Innsbruck. http://www.gaw-mbh.at/proj_mikrosim.php

Steiner, V., Wrohlich, K., Haan, P., Geyer, J. (2008): Documentation of the tax-benefit microsimulation model STSM, Version 2008. Data Documentation No. 31, DIW Berlin.

van Soest, A. (1995): Structural models of family labor supply. A discrete choice approach. Journal of Human Resources 30, 63-88. 


\section{Appendix}

Table A-1: Labor supply estimation results using EU-SILC data

\begin{tabular}{|c|c|c|c|c|c|}
\hline & $\begin{array}{l}\text { flexible } \\
\text { couples } \\
\text { category }\end{array}$ & $\begin{array}{l}\text { women } \\
\text { with } \\
\text { inflexible } \\
\text { spouse } \\
\text { category }\end{array}$ & $\begin{array}{c}\text { single } \\
\text { women } \\
\text { category }\end{array}$ & $\begin{array}{c}\text { men } \\
\text { with } \\
\text { inflexible } \\
\text { spouse } \\
\text { category }\end{array}$ & $\begin{array}{c}\text { single } \\
\text { men } \\
\text { category }\end{array}$ \\
\hline \multirow[t]{2}{*}{ monthly net income } & -0.001 & 0.001 & 0.001 & 0.004 & 0 \\
\hline & {$[0.000]$} & {$[0.001]$} & {$[0.001]$} & {$[0.003]$} & {$[0.001]$} \\
\hline \multirow[t]{2}{*}{ monthly net income ${ }^{2}$} & 0 & 0 & 0 & 0 & 0 \\
\hline & {$[0.000]^{* * *}$} & {$[0.000]^{*}$} & {$[0.000]$} & {$[0.000]^{*}$} & {$[0.000]$} \\
\hline \multirow[t]{2}{*}{ women’s leisure time } & -0.055 & 0.091 & 0.087 & & \\
\hline & {$[0.038]$} & {$[0.064]$} & {$[0.038]^{* *}$} & & \\
\hline \multirow[t]{2}{*}{ men’s leisure time } & 0.236 & & & 0.325 & 0.132 \\
\hline & {$[0.045]^{* * *}$} & & & {$[0.118] * * *$} & {$[0.040]^{* * *}$} \\
\hline \multirow[t]{2}{*}{ women’s leisure ${ }^{2}$} & 0.001 & 0.001 & 0 & & \\
\hline & {$[0.000]^{* * *}$} & {$[0.000]^{* * *}$} & {$[0.000]$} & & \\
\hline \multirow[t]{2}{*}{ men’s leisure ${ }^{2}$} & -0.001 & & & -0.001 & -0.001 \\
\hline & {$[0.000]^{* * *}$} & & & {$[0.000] * * *$} & {$[0.000]^{* * *}$} \\
\hline \multirow[t]{2}{*}{ income $\times$ women's leisure } & 0 & 0 & 0 & & \\
\hline & {$[0.000]$} & {$[0.000]^{* *}$} & {$[0.000] * * *$} & & \\
\hline \multirow[t]{2}{*}{ income $\times$ men’s leisure } & 0 & & & 0 & 0 \\
\hline & {$[0.000]$} & & & {$[0.000]^{* *}$} & {$[0.000]$} \\
\hline \multirow[t]{2}{*}{ women’s leisure $\times$ Austrian } & 0.021 & 0.076 & 0.005 & & \\
\hline & {$[0.016]$} & {$[0.028]^{* * *}$} & {$[0.014]$} & & \\
\hline \multirow[t]{2}{*}{ men’s leisure $\times$ Austrian } & 0.023 & & & -0.051 & -0.01 \\
\hline & {$[0.023]$} & & & {$[0.057]$} & {$[0.019]$} \\
\hline \multirow[t]{2}{*}{ women's leisure $\times$ age } & -0.004 & -0.014 & -0.007 & & \\
\hline & {$[0.002]^{* *}$} & {$[0.002]^{* * *}$} & {$[0.001] * * *$} & & \\
\hline \multirow[t]{2}{*}{ women’s leisure $\times$ age $^{2}$} & 0 & 0 & 0 & & \\
\hline & {$[0.000]^{* * *}$} & {$[0.000]^{* * *}$} & {$[0.000] * * *$} & & \\
\hline \multirow[t]{2}{*}{ men's leisure $\times$ age } & -0.007 & & & -0.008 & -0.002 \\
\hline & {$[0.002]^{* * *}$} & & & {$[0.004]^{*}$} & {$[0.001]$} \\
\hline \multirow[t]{2}{*}{ men’s leisure $\times$ age $^{2}$} & 0 & & & 0 & 0 \\
\hline & {$[0.000]^{* * *}$} & & & {$[0.000]^{* *}$} & {$[0.000]$} \\
\hline \multirow[t]{2}{*}{ women’s leisure $\times$ men’s leisure } & 0 & & & & \\
\hline & {$[0.000]$} & & & & \\
\hline \multicolumn{6}{|l|}{ women's leisure $\times$ men's leisure $\times$} \\
\hline Austrian & {$[0.000]$} & & & & \\
\hline \multirow[t]{2}{*}{ Income $\times$ Austrian } & 0.002 & 0.001 & 0.001 & -0.004 & 0.001 \\
\hline & {$[0.000]^{* * *}$} & [0.001] & {$[0.001]$} & [0.003] & {$[0.001]$} \\
\hline
\end{tabular}


Table A-3 continued:

\begin{tabular}{|c|c|c|c|c|c|}
\hline & $\begin{array}{l}\text { flexible } \\
\text { couples } \\
\text { category }\end{array}$ & $\begin{array}{l}\text { women } \\
\text { with } \\
\text { inflexible } \\
\text { spouse } \\
\text { category }\end{array}$ & $\begin{array}{c}\text { single } \\
\text { women } \\
\text { category }\end{array}$ & $\begin{array}{c}\text { men } \\
\text { with } \\
\text { inflexible } \\
\text { spouse } \\
\text { category }\end{array}$ & $\begin{array}{c}\text { single } \\
\text { men } \\
\text { category }\end{array}$ \\
\hline \multirow[t]{2}{*}{ income $^{2} \times$ Austrian } & 0 & 0 & 0 & 0 & 0 \\
\hline & {$[0.000]^{* * *}$} & [0.000] & {$[0.000]^{*}$} & [0.000] & [0.000] \\
\hline \multirow[t]{2}{*}{ women's leisure $\times$ somewhat handicapped } & 0.007 & 0.007 & 0.065 & & \\
\hline & [0.010] & [0.012] & {$[0.012]^{* * *}$} & & \\
\hline \multirow[t]{2}{*}{ women's leisure $\times$ severely handicapped } & 0.005 & 0.013 & 0.008 & & \\
\hline & [0.005] & {$[0.007]^{*}$} & {$[0.006]$} & & \\
\hline \multirow[t]{2}{*}{ men's leisure $\times$ somewhat handicapped } & 0.026 & & & 0.046 & 0.036 \\
\hline & {$[0.008]^{* * *}$} & & & {$[0.022]^{* *}$} & {$[0.009] * * *$} \\
\hline \multirow[t]{2}{*}{ men's leisure $\times$ severely handicapped } & & & & 0.023 & 0.019 \\
\hline & & & & {$[0.012]^{*}$} & {$[0.007]^{* * *}$} \\
\hline \multirow[t]{2}{*}{ women's leisure $\times$ child aged $0-2$} & 0.059 & 0.06 & 0.085 & & \\
\hline & {$[0.006] * * *$} & {$[0.013]^{* * *}$} & {$[0.015]^{* * *}$} & & \\
\hline \multirow[t]{2}{*}{ women's leisure $\times$ child aged 3-10 } & 0.033 & 0.045 & 0.028 & & \\
\hline & {$[0.004]^{* * *}$} & {$[0.008]^{* * *}$} & {$[0.007]^{* * *}$} & & \\
\hline \multirow[t]{2}{*}{ women's leisure $\times$ child aged 11-18 } & 0.003 & 0.006 & 0.021 & & \\
\hline & [0.004] & [0.006] & {$[0.007]^{* * *}$} & & \\
\hline \multirow[t]{2}{*}{ men's leisure $\times$ child aged $0-2$} & 0.004 & & & 0.006 & 0.01 \\
\hline & [0.006] & & & [0.028] & [0.030] \\
\hline \multirow[t]{2}{*}{ men's leisure $\times$ child aged 3-10 } & -0.004 & & & 0.019 & -0.009 \\
\hline & {$[0.005]$} & & & {$[0.015]$} & {$[0.026]$} \\
\hline \multirow[t]{2}{*}{ men's leisure $\times$ child aged $11-18$} & -0.007 & & & -0.006 & -0.01 \\
\hline & [0.004] & & & [0.012] & [0.016] \\
\hline Observations & 40872 & 4668 & 5856 & 900 & 3800 \\
\hline
\end{tabular}

Standard errors in brackets; ${ }^{*}$ significant at $10 \% ;{ }^{* *}$ significant at $5 \% ;{ }^{* * *}$ significant at $1 \%$

Source: ATTM and SILC (2006) 